\title{
Characteristics of fermented vinegar using mulberry and its antioxidant activity
}

\author{
Se-In Bang ${ }^{1}$, Geon Hyeong Gwon ${ }^{2}$, Eun Ju Cho ${ }^{1}$, Ah Young Lee ${ }^{2 *}$, Weon Taek Seo ${ }^{2 *}$ \\ ${ }^{1}$ Department of Food Nutrition and Science, Pusan National University, Busan 46241, Korea \\ ${ }^{2}$ Department of Food Science, Gyeongnam National University of Science and Technology, Jinju 52725, Korea
}

\section{오디를 이용한 발효식초의 특성 및 항산화 효과 \\ 방세인 ${ }^{1} \cdot$ 권건형 $^{2} \cdot$ 조은주 ${ }^{1} \cdot$ 이아영 ${ }^{2 *}$ - 서원택 ${ }^{2 *}$ \\ ${ }^{1}$ 부산대학교 식품영양학과, ${ }^{2}$ 경남과학기술대학교 식품과학부}

\begin{abstract}
This study was carried out to investigate the physicochemical characteristics and antioxidant properties of mulberry

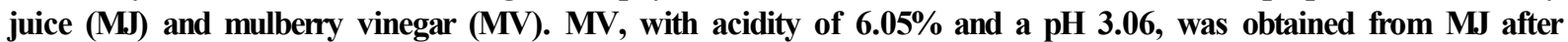
8 days with alcohol fermentation and 20 days with acetic acid fermentation at $30^{\circ} \mathrm{C}$. After fermentation, the major sugars in MV were lactose, glucose, and fructose, showing $1,310.06,293.20$, and $41.25 \mathrm{mg} \%$, respectively. The major organic acids in MV were acetic acid $(2,725.59 \mathrm{mg} \%)$, citric acid $(524.66 \mathrm{mg} \%)$, and succinic acid $(480.63$ $\mathbf{m g} \%$ ). The total free amino acid content of MV, such as lysine, arginine, phenylalanine, and tyrosine, was 34.52 mg\%. MJ and MV showed radical scavenging activities with respect to 1,1-diphenyl-2-picrylhydrazyl (DPPH), hydroxyl $(\mathrm{OH})$, superoxide anion $\left(\mathrm{O}_{2}{ }^{-}\right)$, and nitric oxide (NO) radicals in dose-dependent manner, which were closely related to the total polyphenol and flavonoid contents in MJ and MV. In addition, a strong scavenging effect with regards to the $\mathrm{OH}$ radical was observed in $\mathrm{MJ}$ and $\mathrm{MV}$, an $\mathrm{IC}_{50}$ value of $0.04 \mu \mathrm{g} / \mathrm{mL}$. In particular, $\mathrm{MV}$ showed a higher $\mathrm{O}_{2}^{-}$radical scavenging activity than that of $\mathrm{MJ}$. These results suggest that $\mathrm{MV}$ can be used as a functional vinegar with antioxidant activity against free radicals.
\end{abstract}

Key words : mulberry, fermented vinegar, antioxidant activity, acetic acid, free radical

\section{서 론}

인체 내 세포의 정상적인 대사 과정에서 생성되는 활성산 소종(reactive oxygen species, ROS)은 superoxide dismutase (SOD), glutathione peroxidase, catalase와 같은 체내 항산화 효소에 의해 적절하게 제거되어 세포 내 신호 전달과 생리적 기능이 원활하게 이루어지도록 하지만, 과도한 ROS의 생성 은 산화적 스트레스를 유발하여 세포의 구성 성분인 지질, 단
백질 및 $\mathrm{DNA}$ 를 손상시키고, 노화, 암, 동맥경화, 퇴행성 신경 질환 등 다양한 질환의 주요한 위험 요인으로 알려져 있다 (Furukawa 등, 2004). Nitric oxide(NO), peroxynitrite(ONOO), nitrogen dioxide $\left(\mathrm{NO}_{2}\right)$ 등을 포함하는 활성질소종(reactive nitrogen species, RNS) 또한 생체 내 세포나 세포 소기관의 손상을 진행시키는 것으로 알려져 있으며, 특히 $\mathrm{NO}$ 는 $\mathrm{O}_{2}{ }^{-}$와 쉽게 반응하여 반응성이 매우 높은 산화제인 $\mathrm{ONOO}^{-}$를 생성 하여 생체 분자의 산화적 손상 및 세포 내 미토콘드리아 손상

\footnotetext{
*Corresponding author. E-mail : aylee@gntech.ac.kr, Phone : +82-55-751-3278, Fax : +82-55-751-3279

E-mail : wtseo@gntech.ac.kr, Phone : +82-55-751-3276, Fax : +82-55-751-3279
}

Received 13 April 2020; Revised 24 May 2020; Accepted 26 May 2020.

Copyright (c) The Korean Society of Food Preservation.

This is an Open Access article distributed under the terms of the Creative Commons Attribution Non-Commercial License (http://creativecommons.org/licenses/by-nc/4.0) which permits unrestricted non-commercial use, distribution, and reproduction in any medium, provided the original work is properly cited. 
을 야기시킨다(Darley-Usmar 등, 1995; Patel 등, 1999). 최근 에는 식품을 통해 섭취하는 비타민 $\mathrm{C}$, 비타민 $\mathrm{E}$, 폴리페놀 화합물 등이 체내에서 항산화제로 작용하여 산화에 대한 손 상을 개선시킬 수 있다는 연구가 보고됨에 따라 독성 및 부작 용에 대한 문제가 제기되고 있는 합성 항산화제보다 천연물 또는 식품 유래의 천연 항산화제에 대한 연구가 활발하게 이 루어지고 있다(Byun 등, 2020; Choi 등, 2015).

식초는 가장 오래된 대표적인 발효 식품 중의 하나로, 음식 을 조리할 때 특유의 향미를 부여하여 맛을 풍부하게 하고, 식욕을 증진시키는 조미료로 많이 이용되어왔다. 뿐만 아니 라, 체내에서 쉽게 분해될 수 있고, 소화액의 분비를 촉진시켜 소화기관의 운동을 활발하게 한다고 알려져 있으며, 변비개선, 피로회복 등의 효과가 있는 건강식품이다(Lee 등, 1999a). 식초 는 제조 방법에 따라 빙초산 또는 초산을 희석한 후 아미노산 이나 당류 등의 각종 감미료를 첨가하여 만드는 합성식초와 곡류, 과일즙을 미생물로 발효시켜 제조하는 발효식초(양조식 초)로 구분할 수 있다. 발효식초는 곡류나 과일을 원료로 하여 효모에 의해 당이 알코올로 발효되고 초산균에 의해 알코올이 초산으로 전환되는 발효 공정을 통해 제조되며, 발효 과정에 서 생성되는 초산과 같은 유기산이 인체의 유해한 활성산소를 제거하는 역할을 한다고 알려져 있다(Budak 등, 2014; Turker 등, 2014). 과거에는 합성식초가 생산 기간이 짧고, 가격이 저 렴하여 상업적으로 많이 이용되어 왔으나, 식초 고유의 풍미 가 부족하고 빙초산의 합성 및 정제 시 첨가되는 유해물질의 문제점이 제기되어 최근에는 천연 소재를 활용한 발효식초에 대한 관심이 증가하고 있는 추세이다. 전통 발효식초는 원료 에 따라 초산 이외에 다양한 유기산, 유리당, 아미노산 및 기 능성 물질들이 포함되어 있다고 보고되고 있으며, 이에 따라 현미, 사과, 감, 배, 매실, 복분자 등 곡류와 과실을 이용한 식 초를 개발하고자 하는 시도가 활발히 이루어지고 있는 추세이 다(Park 등, 2016). 또한, 전통 발효식초는 노화 방지, 당뇨 및 동맥경화 예방뿐만 아니라, 피부 미용 개선, 체지방 감소 효과 등 다양한 생리활성이 보고되어 단순히 조미료가 아닌 건강식 품으로서 소비자들의 관심이 꾸준히 증가하고 있다(Hwang 등, 2016; Jeong 등, 2016; Lee 등, 2012).

오디(mulberry)는 뽕나무과(Moraceae)에 속하는 뽕나무 (Morus alba L.)의 열매로서 예로부터 '상심자'로 불리며, 당 뇨, 피로회복, 빈혈, 고혈압, 관절 치료제로 널리 이용되어 왔 다(Kim, 1991). 오디 추출물에 대한 생리활성 연구로는 항당 뇨, 항염증, 항산화 등의 효과가 보고되어 있으며(Son과 Choi, 2013), 각종 유기산을 비롯하여 anthocyanin 색소를 다 량 함유하고 있다고 알려져 있어 천연색소 자원으로 활용될 가능성이 높을 것으로 전망된다(Song 등, 2009). 그러나 오디 는 크기가 작을 뿐만 아니라, 수분 함량이 높아 부패가 잘 일
어나고 저장성이 떨어지기 때문에 그 이용률이 현저히 낮고, 현재 대부분은 오디를 착즙하여 오디잼, 오디즙, 오디시럽 등 일부의 형태로만 이용되고 있어 다양한 가공 식품 제조 및 특성에 관한 연구가 요구되고 있다(Kim과 Ryu, 2000). 지금 까지 오디에 관한 연구로는 오디의 형태와 이화학적 특성 (Kim 등, 1999), 오디 영양성분 및 색소(Kim 등, 2010), 오디 가루를 첨가한 식빵과 절편의 품질 특성에 대한 연구가 주로 이루어져 있으나, 오디를 이용한 발효식초 제조 및 품질 특성 규명, 이를 이용한 생리 활성 연구 등은 미흡한 실정이다.

따라서 본 연구에는 오디를 이용하여 알코올 및 초산 발효 를 통해 전통 발효식초를 제조한 뒤, 이화학적 성분 분석 및 대표적인 시판 과실 발효식초 중 하나인 사과 식초와 함께 라디칼 소거 활성을 비교 분석하여 항산화 효능을 가진 기능 성 식품으로서의 이용 가능성에 대해 알아보고자 하였다.

\section{재료 및 방법}

\section{재료 및 시약}

본 연구에 사용된 오디는 2018년 6월에 경남 하동군에서 수확한 오디(과상 2 호)였으며, 수확 후 $-40^{\circ} \mathrm{C}$ 냉동고에서 냉 동 보관하였고, 필요에 따라 상온에서 해동하여 사용하였다 (Fig. 1), 항산화 활성을 비교하기 위한 사과 식초(Ottogi Co., Ltd., Seoul, Korea)는 마트에서 구입하여 사용하였다. 1,1Diphenyl-2-picrylhydrazyl(DPPH)와 2-deoxyribose는 Sigma Chemical Co.(St. Louis, MO, USA)에서 구입하여 사용하였 고, hydrogen peroxide $\left(\mathrm{H}_{2} \mathrm{O}_{2}\right)$, sodium hydroxide $(\mathrm{NaOH})$, acetic acid는 Junsei Chemical Co.(Tokyo, Japan)에서 구입하 였다. Tiobarbituric acid(TBA)와 trichloroacetic acid(TCA)는 각각 Acros Organics(New Jersey, USA)와 Kanto Chemical Co., Inc.(Tokyo, Japan)에서 구입하여 사용하였다. $\mathrm{FeSO}_{4}$ $7 \mathrm{H}_{2} \mathrm{O}$ 는 Daejung Chemicals \& Metals Co., Ltd.(Siheung,

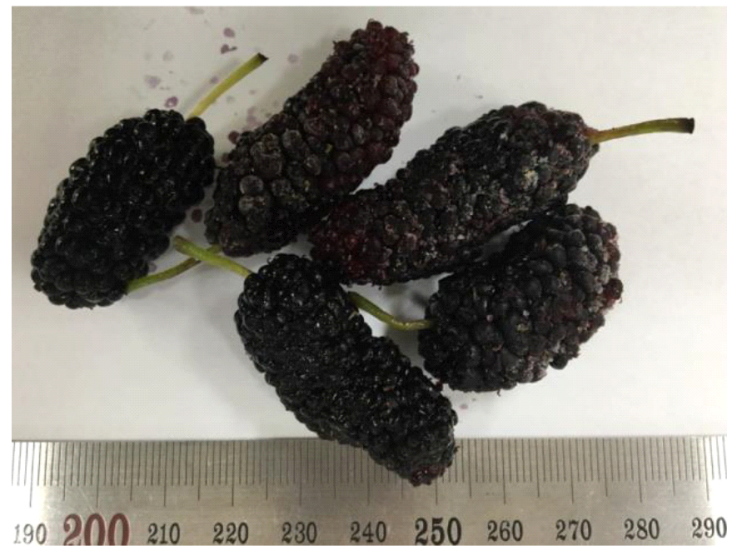

Fig. 1. Mulberry used in this study. 
Korea)에서, phenezine methsulfate(PMS), NADH disodium salt, 그리고 nitrotetrazolium blue chloride(NBT)는 Bio Basic Inc.(Toronto, Canada)에서 구입하였다.

\section{사용 균주 및 종균배양}

알코올 발효를 위한 효모 종균으로 Saccharomyces cerevisiae $\mathrm{KCCM} 11215$ 균주를 사용하였으며, 초산발효를 위한 초산 균 종균은 본 실험실에서 분리하여 보관하고 있는 Acetobacter pasteurianus A8(Shin, 2013) 균주를 사용하였다. 효모와 초 산균 보존용 배지는 YPDA $(0.5 \%$ yeast extract, $0.5 \%$ peptone, $2 \%$ dextrose, $1.5 \%$ agar) 배지를 사용하였다. 효모 및 초산균 종균 배양은 엿기름배지(정수 $1 \mathrm{~L}$ 에 엿기름가루 $200 \mathrm{~g}$ 가하 고, $60^{\circ} \mathrm{C}$ 에서 2 시간 당화 후 여과하여 여액을 $1 \mathrm{~L}$ 로 조정한 후 $121^{\circ} \mathrm{C}$ 에서 15 분 멸균)를 사용하였다. 효모 종균 배양을 위 해 엿기름배지 $100 \mathrm{~mL}$ 가 들어 있는 $250 \mathrm{~mL}$ Erlenmeyer flask에 YPDA배지에서 계대배양한 S. cerevisiae $\mathrm{KCCM}$ 11215 균주를 1 백금이 접종하고 $30^{\circ} \mathrm{C}$ 진탕 배양기(IS-971RF model, Jeiotech Co., Seoul, Korea)에서 $160 \mathrm{rpm}$ 으로 2일간 진탕 배양하여 알코올 발효를 위한 주모로 사용하였다. 초산 균 종초 배양을 위해 $1 \%(\mathrm{v} / \mathrm{v})$ 에탄올을 보충한 엿기름배지 $100 \mathrm{~mL}$ 가 들어 있는 $250 \mathrm{~mL}$ Erlenmeyer flask에 YPDA에 서 계대배양한 A. pasteurianus $\mathrm{A} 8$ 를 1 백금이 접종하고 $30^{\circ} \mathrm{C}$ 진탕 배양기(IS-971RF model, Jeiotech Co., Seoul, Korea)에 서 $160 \mathrm{rpm}$ 으로 3 일간 진탕 배양하여 초산발효를 위한 종초 로 사용하였다.

\section{오디 주스와 오디 식초의 제조}

실온에서 해동한 오디에 주스의 수득량을 높이기 위해 상 업용 pectinase인 plantase ${ }^{\mathrm{TM}}$ (Bision Co., Seoul, Korea)를 주 스 양에 대하여 $0.4 \%$ 를 첨가하고, $45^{\circ} \mathrm{C}$ 에서 2 시간 처리한 후 천으로 걸러 오디주스를 제조하였다(Kim 등, 2017; Lee 등, 2018). 오디 주스에 설탕을 가하여 당 농도를 $15^{\circ} \mathrm{Brix}$ 로 조 정하였으며, 제조한 오디주스는 2 L 광구병(SCHOTT, Mainz, Germany)에 $1 \mathrm{~L}$ 분주하여 $80^{\circ} \mathrm{C}$ 에서 15 분간 살균한 후 사용 하였다. 살균 처리 후 상온으로 냉각한 오디 주스에 맥아 추 출액 배지에서 종초 배양한 효모 주모를 $5 \%$ 부피로 접종한 뒤 $30^{\circ} \mathrm{C}$ 에서 8 일간 정치, 발효시켜 초산 발효를 위한 알코올 발효 기질을 제조하였다. 알코올 발효가 끝난 후 $30^{\circ} \mathrm{C}$ 에서 3 일간 진탕 배양한 초산균 종초를 $5 \%$ 부피비율로 접종하고, $30^{\circ} \mathrm{C}$ 에서 20 일간 정치하여 발효시켰다.

\section{$\mathrm{pH}$ 및 총 산도 측정}

시료는 원심분리기(MF-550, Hanil Science Industrial Co., Kimpo, Korea)에서 3,000 rpm으로 15 분간 원심 분리한 후 상
등액을 취하여 $\mathrm{pH}$ meter(model 3510 , Jenway, UK)를 사용하 여 $\mathrm{pH}$ 를 측정하였으며, 산도는 원심 분리한 시료 $1 \mathrm{~mL}$ 를 $\mathrm{pH}$ $8.2 \pm 0.1$ 까지 중화시키는데 소요된 $0.1 \mathrm{~N} \mathrm{NaOH}$ 의 소비 $\mathrm{mL}$ 수를 구하고, 아래 식에서와 같이 환산하였다.

Total acidity $(\%$, acetic acid $)=0.6 \times 0.1 \mathrm{~N} \mathrm{NaOH}$ 소비량 $(\mathrm{mL})$

\section{유리당과 유기산 분석}

유리당과 유기산은 HPLC(Agilent 1200 series, Agilent Co., Forest Hill, Vic, Australia)를 이용하여 분석하였다(Cho 등, 2008). 유리당을 분석하기 위해 시료 $5 \mathrm{~g}$ 에 물 $25 \mathrm{~mL}$ 를 가하여 녹인 후 acetonitrile로 $50 \mathrm{~mL}$ 까지 채웠다. 이 용액을 sep-pak $\mathrm{NH}_{2}$ column(Waters Co., Milford, MA, USA)과 $0.45 \mu \mathrm{m}$ membrane filter(Dismic-25CS, Toyoroshikaisha Ltd., Tokyo, Japan)로 여과한 뒤 시험용액으로 사용하였다. 당 분 석 column(Polyamine II, $4.6 \times 150 \mathrm{~mm}, 5 \mu \mathrm{m}$, YMC Co., Kyoto, Japan)에 시험용액 $20 \mu \mathrm{L}$ 을 주입하고, $35^{\circ} \mathrm{C}$ 에서 이동 상 용매(acetonitrile:water $=70: 30(\mathrm{v} / \mathrm{v})$ 를 $1.0 \mathrm{~mL} / \mathrm{min}$ 속도 로 이동시키면서 refractive index(RI, Agilent 1200 series) 검 출기 상에서 당을 검출하였다.

유기산 분석을 위해 시료를 원심분리기에서 $3,000 \mathrm{rpm}$ 으 로 15 분간 원심분리한 후 상등액을 $0.2 \mu \mathrm{m}$ membrane filter(Dismic-25CS, Toyoroshikaisha Ltd.)로 여과하였다. 전 처리한 시료 $20 \mu \mathrm{L}$ 를 TSK gel ODS- $100 \mathrm{~V}$ column $(4.6 \times 250$ $\mathrm{mm}, 5 \mu \mathrm{m}$, Tosoh Corp., Tokyo, Japan)이 장착된 HPLC 시 스템에 주입하고, $30^{\circ} \mathrm{C}$ 에서 이동상 용매 $(0.1 \%$ phosphoric acid)를 $1.0 \mathrm{~mL} / \mathrm{min}$ 속도로 이동시키면서 $\mathrm{UV}$ 검출기 (Agilent 1200 series, Agilent Co., CA, USA) 210 nm에서 유기산을 검출하였다. 유기산은 같은 조건으로 분석한 표준 유기산의 검량선과 비교하여 정량하였으며, 각 실험은 3 회 반복 수행하여 평균 및 표준편차로 나타내었다.

\section{유리아미노산 분석}

유리아미노산은 시료 $5 \mathrm{~mL}$ 에 $5 \% \mathrm{TCA}$ 를 $5 \mathrm{~mL}$ 첨가하여 원심 분리(10,000 rpm, $10 \mathrm{~min})$ 한 다음 $0.22 \mu \mathrm{m}$ membrane filter로 여과하여 얻은 상층액을 아미노산 자동분석기(Model L-8900, Hitachi, Tokyo, Japan)를 이용하여 분석하였다(Choi 등, 2019). 각 실험은 3 회 반복 수행하여 평균 및 표준편차로 나타내었다.

\section{총폴리페놀 및 총플라보노이드 함량 측정}

총폴리페놀 함량을 측정하기 위해 시료 $100 \mu \mathrm{L}$ 와 $10 \%$ Folin-Ciocalteu's phenol reagent $200 \mu \mathrm{L}$ 를 혼합한 뒤 700 $\mathrm{mM} \mathrm{Na} \mathrm{CO}_{3} 700 \mu \mathrm{L}$ 를 잘 섞은 후 30 분간 상온에 방치하였 
다. 반응이 끝난 후 $650 \mathrm{~nm}$ 에서 흡광도를 측정하였고, gallic acid를 이용한 검량선과 비교하여 $\mu \mathrm{g}$ gallic acid equivalents $(\mathrm{GAE}) / \mathrm{mL}$ 로 총페놀 함량을 나타내었다.

총플라보노이드 함량을 측정하기 위해 시료 $150 \mu \mathrm{L}$ 와 $5 \%$ $\mathrm{NaNO}_{2} 75 \mu \mathrm{L}$ 를 섞은 후 6분간 실온에서 방치하였으며, $10 \%$ $\mathrm{AlCl}_{3} 150 \mu \mathrm{L}$ 를 첨가하여 다시 5 분간 방치하였다. 그 후 $1 \mathrm{~N}$ $\mathrm{NaOH} 750 \mu \mathrm{L}$ 를 혼합하여 15 분간 반응시킨 다음 $492 \mathrm{~nm}$ 에 서 흡광도를 측정하였다. 총플라보노이드 함량은 quercetin을 이용한 검량선과 비교하여 $\mu \mathrm{g}$ quercetin equivalents $(\mathrm{QE}) / \mathrm{mL}$ 로 나타내었다.

\section{1,1-Diphenyl-2-picrylhydrazyl(DPPH) 라디칼 소거능}

$\mathrm{DPPH}$ 라디칼 소거능은 Hatano 등(1989)의 방법으로 측정 하였다. Ethanol에 녹인 각 농도별 시료 $100 \mu \mathrm{L}$ 와 $60 \mu \mathrm{M}$ $\mathrm{DPPH}$ 용액 $100 \mu \mathrm{L}$ 를 96-well plate에 혼합하여 30분간 실온 에 방치시킨 후, $540 \mathrm{~nm}$ 에서 흡광도를 측정하였다. $\mathrm{DPPH}$ 라 디칼 소거능은 다음 식에 따라 계산하였으며, 시료를 첨가하 지 않은 대조군과 비교하여 라디칼 소거효과를 백분율과 $\mathrm{IC}_{50}$ 로 나타내었다.

DPPH radical scavenging activity $(\%)=100-\left[\left(A_{s}-A_{b}\right) 100 / A_{c}\right]$

$\mathrm{A}_{\mathrm{s}}$ 는 농도별 시료를 첨가한 실험군, $\mathrm{A}_{b}$ 는 blank를 첨가한 대 조군, $\mathrm{A}_{c}$ 는 시료를 첨가하지 않은 대조군의 흡광도 값을 뜻한다.

\section{Hydroxyl(OH) 라디칼 소거능}

$\mathrm{OH}$ 라디칼 소거능은 Chung 등(1997)의 방법으로 측정하 였다. Fenton 반응에 따라 $10 \mathrm{mM} \mathrm{FeSO} 4 \cdot \mathrm{H}_{2} \mathrm{O}$-EDTA에 10 $\mathrm{mM}$ 의 2-deoxyribose solution과 각 농도별 시료를 혼합한 다 음, $10 \mathrm{mM}$ 의 $\mathrm{H}_{2} \mathrm{O}_{2}$ 를 첨가하여 $37^{\circ} \mathrm{C}$ 에서 4시간 배양하였다. 배양된 혼합액에 $2.8 \% \mathrm{TCA}$ 와 $1.0 \% \mathrm{TBA}$ solution를 넣은 후 20 분간 끓여 식힌 뒤, $490 \mathrm{~nm}$ 에서 흡광도를 측정하였다. $\mathrm{OH}$ 라디칼 소거능은 다음 식에 따라 계산하였으며, 시료를 첨가하지 않은 대조군과 비교하여 라디칼 소거효과를 백분율 과 $\mathrm{IC}_{50}$ 로 나타내었다.

$\mathrm{OH}$ radical scavenging activity $(\%)=100-\left[\left(\mathrm{A}_{\mathrm{s}}-\mathrm{A}_{\mathrm{b}}\right) 100 / \mathrm{A}_{\mathrm{c}}\right]$

$\mathrm{A}_{\mathrm{s}}$ 는 농도별 시료를 첨가한 실험군, $\mathrm{A}_{b}$ 는 blank를 첨가한 대 조군, $\mathrm{A}_{\mathrm{c}}$ 는 시료를 첨가하지 않은 대조군의 흡광도 값을 뜻한다.

\section{Nitric oxide(NO) 라디칼 소거능}

$\mathrm{NO}$ 라디칼 소거능은 Marcocci 등(1994)의 방법으로 측정 하였다. $5 \mathrm{mM} \mathrm{SNP}$ solution과 methanol에 녹인 각 농도별
시료를 혼합하여 실온에서 150 분간 반응시켰고, 이 반응 혼 합액을 Griess reagent와 동량으로 96-well plate에 주입하여 실온에서 30 분간 배양한 뒤 $540 \mathrm{~nm}$ 에서 흡광도를 측정하였 다. NO 라디칼 소거능은 다음 식에 따라 계산하였으며, 시료 를 첨가하지 않은 대조군과 비교하여 라디칼 소거효과를 백 분율과 $\mathrm{IC}_{50}$ 로 나타내었다.

NO radical scavenging activity $(\%)=100-\left[\left(\mathrm{A}_{s}-\mathrm{A}_{\mathrm{b}}\right) 100 / \mathrm{A}_{c}\right]$

$\mathrm{A}_{\mathrm{s}}$ 는 농도별 시료를 첨가한 실험군, $\mathrm{A}_{\mathrm{b}}$ 는 blank를 첨가한 대조군, $\mathrm{A}_{c}$ 는 시료를 첨가하지 않은 대조군의 흡광도 값을 뜻 한다.

\section{Superoxide anion $\left(\mathrm{O}_{2}^{-}\right)$라디칼 소거능}

$\mathrm{O}_{2}{ }^{-}$라디칼 소거능은 Nishikimi 등(1972)의 방법에 따라 측정하였다. 각 농도별 시료에 $0.1 \mathrm{M}$ Tris- $\mathrm{HCl}, 0.1 \mathrm{mM}$ PMS, $0.5 \mathrm{mM} \mathrm{NBT}$, 그리고 $0.5 \mathrm{mM} \mathrm{NADH}$ 를 혼합하여 실 온에서 10 분간 반응시킨 후, $560 \mathrm{~nm}$ 에서 흡광도를 측정하였 다. $\mathrm{O}_{2}^{-}$라디칼 소거능은 다음 식에 따라 계산하였으며, 시료 를 첨가하지 않은 대조군과 비교하여 라디칼 소거효과를 백 분율과 $\mathrm{IC}_{50}$ 로 나타내었다.

$\mathrm{O}_{2}^{-}$radical scavenging activity $(\%)=100-\left[\left(\mathrm{A}_{\mathrm{s}}-\mathrm{A}_{\mathrm{b}}\right) 100 / \mathrm{A}_{\mathrm{c}}\right]$

$\mathrm{A}_{\mathrm{s}}$ 는 농도별 시료를 첨가한 실험군, $\mathrm{A}_{b}$ 는 blank를 첨가한 대조군, $\mathrm{A}_{\mathrm{c}}$ 는 시료를 첨가하지 않은 대조군의 흡광도 값을 뜻 한다.

\section{통계분석}

본 실험에서 측정한 결과는 평균(mean) \pm 표준편차(SD)로 나타내었으며, 통계프로그램인 Statistical Package for the Social Sciences(SPSS version 25, IBM Corporation, Almonk, $\mathrm{NY}, \mathrm{USA}$ )를 이용하였다. 오디 주스와 오디 식초간의 이화학 적 특성 및 성분 분석은 Student's t-test를 통해 유의성을 검 증하였으며, 라디칼 소거 활성은 분산분석(ANOVA, analysis of variance)을 구한 후 Duncan's multiple range test를 사용 하여 변인과의 차이를 분석하였다. 모든 통계적인 유의성은 $\mathrm{p}<0.05$ 수준에서 검증하였다.

\section{결과 및 고찰}

\section{오디 식초의 $\mathrm{pH}$ 및 산도}

오디 식초 제조 과정에서 알코올 발효 과정 중 당도와 알 코올 함량의 변화를 측정한 결과를 Fig. $2 \mathrm{~A}$ 에 나타내었다. 알 
코올 발효가 진행됨에 따라 당도가 초기( 0 일 $)$ 에 $14{ }^{\circ} \mathrm{Brix}$ 에서 2 일 째 $6{ }^{\circ} \mathrm{Brix}$ 로 급격하게 감소하였고, 그 후 완만하게 감소 하여 말기( 8 일)에 $5{ }^{\circ} \mathrm{Brix}$ 로 나타났다. 알코올 함량은 발효가 진행됨에 따라 증가하였는데, 초기 $(0$ 일)에 $0 \%$ 에서 2 일째에 $4.0 \%$ 로 증가하였으며, 말기(8일)에는 $5.8 \%$ 로 나타났다. 따라 서, 알코올 발효 과정을 통해 효모가 당을 발효 기질로 이용 하여 알코올을 생성한 것으로 사료된다.

초산 발효과정 중 오디 식초의 $\mathrm{pH}$ 및 산도 측정 결과를 Fig. 2B에 나타내었다. 발효 전 오디 식초의 총 산도는 초기(0 일)에 $0.40 \%$ 에서 4 일과 8 일째 각각 $2.88 \%$ 와 $5.20 \%$ 로 급격하 게 증가하였으며, 말기(20일)에 $6.05 \%$ 를 나타내는 것을 확인 하였다. 오디 식초의 $\mathrm{pH}$ 는 초기( 0 일)에 3.90 으로 나타났으며, 4 일째와 8 일째 각각 $3.46,3.13$ 로 감소하였고, 발효 후 20 일째 $\mathrm{pH}$ 는 3.06 으로 나타나 총 산도가 증가함에 따라 $\mathrm{pH}$ 가 감소되 는 것을 알 수 있었다. 일반적으로 초산 발효가 진행이 되면 초산균이 알코올을 에너지원으로 이용하거나, 발효기질로 사 용하여 유기산 acetic acid를 생성하기 때문에 산도가 높아지 고 $\mathrm{pH}$ 가 낮아지는 현상이 발생한다. 본 연구에서도 발효가 진 행됨에 따라 초산균에 의한 유기산의 생성으로 $\mathrm{pH}$ 가 다소 낮 아지는 경향을 나타낸 것으로 사료된다. 식품 공전에서는 식 초에 대한 품질 규격으로 총산 함량을 4-20\% 범위로 정해놓 았으며(KFDA, 2020), 오디 식초의 산도는 이러한 기준에 적 합한 것을 확인하였다.
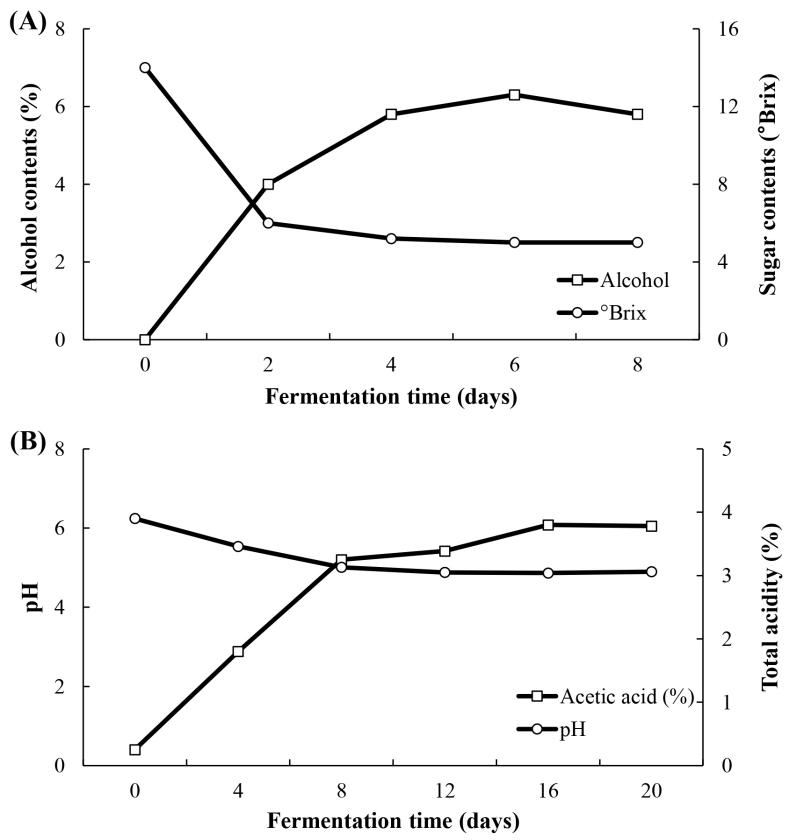

Fig. 2. Changes in alcohol and sugar contents of mulberry vinegar during alcohol fermentation for 8 days at $30^{\circ} \mathrm{C}$ (A).

Changes in $\mathrm{pH}$ and total acidity of MV during acetic acid fermentation for 20 days at $30^{\circ} \mathrm{C}(\mathrm{B})$

\section{오디 주스와 오디 식초의 유리당 변화}

오디 주스와 식초의 유리당 함량을 측정한 결과를 Table 1 에 나타내었다. 오디 주스의 총 유리당 함량은 $5,514.17 \mathrm{mg} \%$ 로 주요 성분에는 fructose $(2,870.83 \mathrm{mg} \%)$, glucose $(2,643.34$ $\mathrm{mg} \%$ )가 확인되었으며, 오디 식초의 경우 총 유리당 함량이 $1,644.50 \mathrm{mg} \%$ 로 감소하였고, 주요 성분은 lactose $(1,310.06$ $\mathrm{mg} \%)$, glucose $(293.20 \mathrm{mg} \%)$, fructose $(41.25 \mathrm{mg} \%)$ 으로 나타 났다. 이러한 결과는 이전 연구에서 섬애약쑥 추출물로 제조 한 식초가 발효 기간 동안 glucose와 fructose의 함량이 감소 하였다는 결과와 유사하였다(Shin 등, 2017). Hong 등 (2012a)의 연구에 따르면, 유리당이 감소하는 것은 발효 과정 중 초산균의 대사 작용으로 인해 당이 대부분 산으로 전환되 고, 일부는 에너지원으로 이용되기 때문이라고 보고하였으 며, $\operatorname{Sim}$ 등(2016)의 연구에서는 식초 발효 시 초산균은 알코 올을 이용하여 산을 생성하며 당이 감소하는 것은 1 차 알코 올 발효 후 남아있는 효모의 작용으로 인해 당이 분해되기 때문인 것으로 보고하였다. 반면, 오디 식초에서 lactose의 함 량이 증가한 것을 확인할 수 있었는데, 영천지역의 오디를 이 용하여 식초를 제조한 선행연구에서도 발효 후 lactose가 분 석되어 본 실험 결과와 유사한 경향을 나타내었으나, 이에 대 한 추가적인 연구가 필요하다고 생각된다(Chu 등, 2012).

\section{오디 주스와 오디 식초의 유기산 변화}

일반적으로 식초의 유기산 성분은 식초의 품질과 산미에 중요한 영향을 미치는 것으로 알려져 있으며, TCA 회로 활 성화를 통해 젖산 분해를 촉진시키는 기능이 있다고 보고된 바 있다(Nakanc, 1988). 발효 유무에 따른 유기산 함량을 살 펴본 결과(Table 2), 발효 전 오디 주스의 주요 유기산은 citric acid로 $616.74 \mathrm{mg} \%$ 가 함유되어 있었으며, 그 다음으로 succinic acid가 $153.34 \mathrm{mg} \%$, acetic acid가 $12.95 \mathrm{mg} \%$, 그리 고 oxalic acid가 $1.99 \mathrm{mg} \%$ 가 검출되었다. 오디 식초의 경우,

Table 1. Changes in free sugar contents in mulberry juice and mulberry vinegar

\begin{tabular}{cccc}
\hline \multirow{2}{*}{$\begin{array}{c}\text { Free sugar } \\
(\mathrm{mg} \%)\end{array}$} & \multicolumn{2}{c}{ Sample $^{1)}$} & t-value \\
\cline { 2 - 3 } & MJ & MV & \\
\hline Fructose & $2,870.83 \pm 205.59^{2)}$ & $41.25 \pm 8.84$ & $\left.23.816^{* * 3}\right)$ \\
Glucose & $2,643.34 \pm 132.57$ & $293.20 \pm 34.86$ & $29.696^{* * *}$ \\
Lactose & $-4)$ & $1,310.06 \pm 134.34$ & - \\
\hline Total & $5,514.17 \pm 337.86$ & $1,644.50 \pm 161.68$ & \\
\hline
\end{tabular}

${ }^{1)} \mathrm{MJ}$, mulberry juice; MV, mulberry vinegar.

${ }^{2)}$ Values are mean $\pm \mathrm{SD}$

${ }^{3)}$ Significant difference by the Student's t-test $\left({ }^{* *} \mathrm{p}<0.01,{ }^{* * *} \mathrm{p}<0.001\right)$.

${ }^{4}$ Not detected. 
Table 2. Changes in organic acid contents in mulberry juice and mulberry vinegar

\begin{tabular}{cccc}
\hline \multirow{2}{*}{$\begin{array}{c}\text { Organic acid } \\
(\mathrm{mg} \%)\end{array}$} & MJ & MV & t-value \\
\cline { 2 - 3 } & $1.99 \pm 0.32^{2)}$ & $-3)$ & - \\
\hline Oxalic acid & $524.66 \pm 27.88$ & $34.381^{* * 4)}$ \\
Citric acid & $616.74 \pm 14.41$ & $480.63 \pm 63.57$ & $-8.916^{*}$ \\
Succinic acid & $153.34 \pm 1.36$ & $2,725.59 \pm 177.33$ & $-26.493^{* *}$ \\
Acetic acid & $12.95 \pm 2.72$ & $2,730.88 \pm 263.86$ & \\
\hline Total & $785.02 \pm 13.45$ & 3,06 & \\
\hline
\end{tabular}

${ }^{1)} \mathrm{MJ}$, mulberry juice; MV, mulberry vinegar.

${ }^{2)}$ Values are mean $\pm \mathrm{SD}$.

${ }^{3)}$ Not detected.

${ }^{4)}$ Significant difference by the Student's t-test $\left({ }^{*} \mathrm{p}<0.05,{ }^{* *} \mathrm{p}<0.01\right)$.

acetic acid가 주요 유기산이었으며, 그 함량은 2,725.59 $\mathrm{mg} \%$ 로 나타났다. 이어서 오디 식초는 citric acid가 524.66 $\mathrm{mg} \%$, succinic acid가 $480.63 \mathrm{mg} \%$ 순으로 높았으며, oxalic acid는 검출되지 않았다. 이전 연구에 따르면 복분자를 이용 한 식초의 경우 acetic acid가 $5,321.71 \mathrm{mg} \%$ 로 가장 많았고 (Hong 등, 2012b), malic acid가 $348.26 \mathrm{mg} \%$, succinic acid가 $140.91 \mathrm{mg} \%$ 순으로 검출되었으며, 포도 과즙을 이용한 고산 도 식초에서는 acetic acid가 $10,085.6-10,351.4 \mathrm{mg} \%$, malic acid가 305.2-317.4 mg\%, citric acid가 279.9-311.7 mg\% 순 으로 높게 나타났다(Woo 등, 2015). 꾸지뽕 발효식초의 유기 산 조성을 측정하였을 때도 acetic acid가 가장 많은 함량을 나타내어(Lee 등, 2019), 발효식초의 주요 유기산이 acetic acid으로 본 연구와 일치하는 경향을 확인할 수 있었으나, 유 기산의 구성 성분과 함량에 차이가 있는 것은 발효 시 이용되 는 과실의 종류, 초산균의 종류, 발효 온도 및 여과방식에 따 라 다르게 나타나는 것으로 알려져 있다(Baek 등, 2016). 또 한, 발효 후 식초에서 발효 전보다 citric acid와 succinic acid 가 증가한 것을 볼 수가 있었는데, 이는 원료에 존재하는 성 분이 식초로 이행되었거나, 발효 중 부산물이 생성되어 나타 난 것으로 생각되며, 체내 TCA cycle에서 이용되는 주요 유 기산으로 생리적 상태에 따라 필요한 물질로 쉽게 전환될 수 있어 생체 내 균형을 유지하는데 도움을 줄 수 있을 것으로 사료된다(Lee 등, 1999b)

\section{오디 주스와 오디 식초의 유리아미노산 변화}

식초에 함유되어 있는 아미노산은 원료에 따라 식초의 맛 에 영향을 주며, 조성과 함량에 따라 식초의 품질에 영향을 미치는 것으로 알려져 있다. 오디 주스와 오디 식초의 유리아 미노산 함량을 분석한 결과를 Table 3에 나타내었다. 오디 주 스와 오디 식초의 아미노산은 각각 31 종이 검출되었으며, 발
Table 3. Changes in free amino acid contents in mulberry juice and mulberry vinegar

\begin{tabular}{|c|c|c|c|}
\hline \multirow{2}{*}{$\begin{array}{c}\text { Free amino acid } \\
(\mathrm{mg} \%)\end{array}$} & \multicolumn{2}{|c|}{ Sample ${ }^{1)}$} & \multirow{2}{*}{ t-value } \\
\hline & MJ & MV & \\
\hline Aspartic acid & $18.29 \pm 0.03^{2)}$ & $0.55 \pm 0.04$ & $597.677^{* * * 3)}$ \\
\hline Threonine & $2.75 \pm 0.00$ & $0.89 \pm 0.66$ & $54.412^{* * * *}$ \\
\hline Serine & $7.78 \pm 0.01$ & $0.26 \pm 0.04$ & $336.006^{* * *}$ \\
\hline Asparagine & $58.76 \pm 0.05$ & $1.22 \pm 0.21$ & $451.801^{* * *}$ \\
\hline Glutamic acid & $13.82 \pm 0.02$ & $1.02 \pm 0.12$ & $185.357^{* * *}$ \\
\hline Sarcosine & $1.03 \pm 0.02$ & $0.48 \pm 0.25$ & $3.751^{\mathrm{NS}}$ \\
\hline$\alpha$-Aminoadipic acid & $0.45 \pm 0.01$ & $0.89 \pm 0.28$ & $-2.713^{\mathrm{NS}}$ \\
\hline Glycine & $1.38 \pm 0.00$ & $0.42 \pm 0.08$ & $20.035^{* * *}$ \\
\hline Alanine & $7.83 \pm 0.02$ & $0.63 \pm 0.07$ & $165.562^{* * *}$ \\
\hline Citrulline & $0.39 \pm 0.01$ & $0.37 \pm 0.15$ & $0.255^{\mathrm{NS}}$ \\
\hline$\alpha$-Amino- $n$-butyricacid & $0.21 \pm 0.01$ & $0.21 \pm 0.05$ & $-0.141^{\mathrm{NS}}$ \\
\hline Valine & $2.86 \pm 0.03$ & $0.81 \pm 0.07$ & $46.518^{* * *}$ \\
\hline Cystein & $2.66 \pm 0.02$ & $2.31 \pm 0.17$ & $3.540^{\mathrm{NS}}$ \\
\hline Methionine & $1.50 \pm 0.00$ & $0.63 \pm 0.08$ & $17.640^{* *}$ \\
\hline Cystathionine & $0.27 \pm 0.01$ & $0.26 \pm 0.06$ & $0.221^{\mathrm{NS}}$ \\
\hline Isoleucine & $2.62 \pm 0.02$ & $1.22 \pm 0.10$ & $24.015^{* *}$ \\
\hline Leucine & $5.29 \pm 0.01$ & $1.69 \pm 0.07$ & $92.275^{* * *}$ \\
\hline Tyrosine & $5.20 \pm 0.02$ & $2.36 \pm 0.12$ & $41.684^{* * *}$ \\
\hline Phenylalanine & $3.71 \pm 0.02$ & $2.99 \pm 0.12$ & $10.280^{* *}$ \\
\hline$\beta$-Alanine & $0.91 \pm 0.00$ & $0.36 \pm 0.02$ & $36.997^{* * *}$ \\
\hline$\beta$-Aminoisobutyric acid & $1.44 \pm 0.02$ & $1.08 \pm 0.05$ & $12.310^{* * *}$ \\
\hline$\gamma$-Amino- $n$-butyric acid & $16.73 \pm 0.01$ & $0.30 \pm 0.02$ & $1,242.097^{* * *}$ \\
\hline 2-Aminoethanol & $0.96 \pm 0.01$ & $-4)$ & - \\
\hline Ammonium chloride & $1.45 \pm 0.00$ & $0.04 \pm 0.00$ & $460.085^{* * *}$ \\
\hline Hydroxylysine & $0.09 \pm 0.00$ & - & - \\
\hline Ornithine & $0.27 \pm 0.00$ & $0.96 \pm 0.00$ & $-189.639^{* * *}$ \\
\hline Lysine & $3.21 \pm 0.01$ & $4.48 \pm 0.01$ & $-176.074^{* * *}$ \\
\hline 1-Methylhistidine & - & $0.02 \pm 0.00$ & - \\
\hline Histidine & $1.65 \pm 0.00$ & $1.14 \pm 0.01$ & $129.060^{* * * *}$ \\
\hline 3-Methylhistidine & - & $0.04 \pm 0.00$ & - \\
\hline Anserine & $2.45 \pm 0.01$ & $2.16 \pm 0.01$ & $64.156^{* * *}$ \\
\hline Carnosine & $0.22 \pm 0.10$ & $0.33 \pm 0.01$ & $-1.914^{\mathrm{NS}}$ \\
\hline Arginine & $6.68 \pm 0.11$ & $4.41 \pm 0.09$ & $27.917^{* * *}$ \\
\hline Total & $172.95 \pm 0.08$ & $34.52 \pm 2.18$ & \\
\hline
\end{tabular}

T)MJ, mulberry juice; MV, mulberry vinegar.

${ }^{2)}$ Values are mean $\pm \mathrm{SD}$.

${ }^{3)}$ Significant difference by the Student's t-test $\left({ }^{* *} \mathrm{p}<0.01,{ }^{* * *} \mathrm{p}<0.001\right.$, NS not significant).

${ }^{4)}$ Not detected. 
효를 하기 전 오디 주스에서는 유리아미노산 함량이 172.95 $\mathrm{mg} \%$ 였으나, 오디 식초는 $34.52 \mathrm{mg} \%$ 로 감소된 것을 확인할 수 있었다. Jo 등(2014)의 연구에서도 배를 이용하여 식초를 제조할 때 초산 발효를 하는 과정에서 유리아미노산의 함량 이 $40 \%$ 이상 감소되었다고 보고하였다. 식초는 초산 발효 과 정 중 원료의 아미노산이 자화되어 전체적으로 함량이 감소 하며, 숙성기간 중에도 아미노산의 함량이 감소하는 것으로 보고되어 있다. 오디 식초의 주요 아미노산은 lysine (4.48 $\mathrm{mg} \%$ ), arginine(4.41 mg\%), phenylalanine (2.99 mg\%), tyrosine $(2.36 \mathrm{mg} \%)$ 순으로 높은 함량을 나타냈으며, 곡류의 제한 아미노산이자 항산화 효과가 있다고 알려진 lysine (Al-Malki, 2015)과 면역 증강 및 비만 예방의 효과가 있다고 보고되어진 ornithine(Moinard 등, 2000; Moon 등, 2012)의 함량이 오디 주스에 비해 증가한 것을 알 수 있었다. 반면, 오디 식초는 주스에 비해 glutamic acid와 aspartic acid가 크 게 감소하는 것으로 나타났는데, 이는 식초를 발효하였을 때 glutamic acid, aspartic acid와 proline의 감소 폭이 크다는 이 전 보고와 유사한 경향을 나타내었다(Yulkimichi 등, 1987). Baek 등(2013)의 연구에 따르면 알코올 발효 종료 후 $\gamma$ -amino- $n$-butyric acid의 함량이 발효 전보다 후에 감소되는 것으로 나타난 결과를 보았을 때, 오디 식초의 $\gamma$-amino- $n$ butyric acid 함량이 감소한 것 또한 여과 방식에 따라 차이를 보일 것으로 예상되며, 이에 따른 추가적인 연구가 필요할 것 으로 생각된다.

\section{오디 주스와 오디 식초의 총폴리페놀 함량 및 총플라보 노이드 함량}

폴리페놀 화합물은 천연물에 많이 함유되어 있는 성분으 로 한 개 이상의 수산기(-OH)를 가지고 있으며, 수소 또는 전 자를 제공함으로써 활성산소에 의해 손상되는 DNA나 세포 막, 단백질 및 효소에 대해 항산화 작용에 중요한 역할을 하 는 물질이라고 알려져 있다(Tsao, 2010). 플라보노이드는 anthocyanidins, tannins, cathechins 등 폴리페놀에 속하는 성 분으로 $\mathrm{C}_{6}-\mathrm{C}_{3}-\mathrm{C}_{6}$ 을 기본 골격으로 하여 노란색 또는 담황색
을 나타내며, 항산화능이 높은 물질이다(Heim 등, 2002). 본 연구에서 제조된 오디 식초의 총폴리페놀과 총플라보노이드 함량을 측정한 결과(Table 4), 각각 $778.06 \mu \mathrm{g} \mathrm{GAE} / \mathrm{mL}$ 와 $294.67 \mu \mathrm{g} \mathrm{QE} / \mathrm{mL}$ 로 발효 전 오디 주스에 비해 다소 감소하 는 경향을 나타내었다. 이전 연구에 따르면 식초의 초산 발효 과정에서 강력한 페놀 분해 작용이 일어나 총페놀 함량이 감 소한다고 보고되었고(Andlauer 등, 2000), 레빗아이 블루베 리로 제조한 식초의 경우, 초산 발효 과정을 통해 anthocyanidins 함량, 총폴리페놀 함량 감소 및 그에 따른 항산화 효 과가 감소하는 경향을 나타내었다(Su와 Chien, 2007).

\section{오디 주스와 오디 식초의 DPPH 라디칼 소거 활성}

$\mathrm{DPPH}$ 라디칼 소거 활성법은 화학적으로 유도되는 안정한 라디칼로서 비교적 간단하면서도 대량으로 측정 가능하고, 재 현성이 높아 다양한 천연소재의 항산화 능력을 알아보기 위 해 가장 쉽고 널리 이용되는 방법 중의 하나이다. 분자 내 라 디칼을 가지고 있는 보라색의 diphenylpicrylhydrazyl이 항산 화제에 의해 전자나 수소를 받아 불가역적으로 안정한 분자 인 diphenylpicrylhydrazine을 형성하여 환원됨에 따라 보라 색에서 탈색되는 원리를 이용하여 라디칼 소거능을 측정한다 (Wang 등, 2005). 오디 주스, 오디 식초와 시판 사과 식초의 $\mathrm{DPPH}$ 라디칼 소거효과를 살펴본 결과(Fig. 3), 모두 10-100 $\mu \mathrm{g} / \mathrm{mL}$ 농도에서 농도 의존적으로 소거 활성이 증가하는 것 을 확인할 수 있었다. 특히 시판 사과 식초의 $\mathrm{IC}_{50}$ 은 671.30 $\mu \mathrm{g} / \mathrm{mL}$ 였으나, 오디 주스와 오디 식초는 각각 $23.75 \mu \mathrm{g} / \mathrm{mL}$ 와 $23.49 \mu \mathrm{g} / \mathrm{mL}$ 로 낮은 값을 보여 효과적인 DPPH 라디칼 소거 활성을 확인할 수 있었으며, 발효에 따른 DPPH 라디칼 소거 능의 큰 차이를 나타내지 않았다. 이전 연구에 따르면 오디 주스의 물 추출물과 메탄올 추출물을 처리하였을 때 $\mathrm{DPPH}$, $\mathrm{OH}$ 및 $\mathrm{O}_{2}^{-}$라디칼 소거능이 농도 유의적으로 증가하였으며, 오디 ethyl acetate 분획물의 $\mathrm{DPPH}$ 소거능 $\mathrm{EC}_{50}$ 값은 64.9 $\mu \mathrm{g} / \mathrm{mL}$ 로 양성대조군으로 사용된 합성 항산화제인 butylated hydroxytoluene의 $\mathrm{EC}_{50}$ 값인 $144.6 \mu \mathrm{g} / \mathrm{mL}$ 보다 2.2배 낮은 값 을 보여 강한 항산화 활성을 나타냈다고 보고한 바 있다(Jun

Table 4. Total polyphenol and total flavonoid contents of mulberry juice and mulberry vinegar

\begin{tabular}{cccc}
\hline & \multicolumn{2}{c}{ Sample $^{1)}$} & t-value \\
\cline { 2 - 3 } & MJ & MV & $4.819^{* * 3)}$ \\
\hline $\begin{array}{c}\text { Total polyphenol contents } \\
(\mu \mathrm{g} \text { gallic acid equivalents } / \mathrm{mL})\end{array}$ & $841.79 \pm 13.90^{2)}$ & $778.06 \pm 18.21$ & $2.403^{\mathrm{NS}}$ \\
$\begin{array}{c}\text { Total flavonoid contents } \\
(\mu \mathrm{g} \text { quercetin equivalents } / \mathrm{mL})\end{array}$ & $378.00 \pm 13.23$ & $294.67 \pm 58.59$ & \\
\hline
\end{tabular}

\footnotetext{
${ }^{1)} \mathrm{MJ}$, mulberry juice; MV, mulberry vinegar.

${ }^{2)}$ Values are mean \pm SD.

${ }^{3)}$ Significant difference by the Student's t-test $\left({ }^{* *} p<0.01\right.$, ${ }^{\mathrm{NS}}$ not significant).
} 

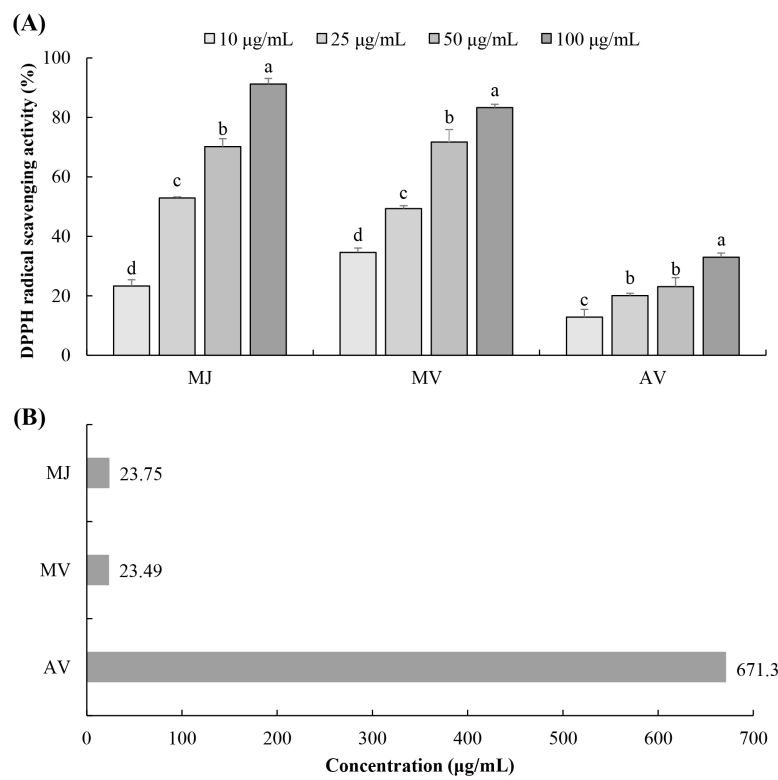

Fig. 3. DPPH radical scavenging activity of mulberry juice, mulberry vinegar, and apple vinegar (A). $\mathrm{IC}_{50}$ values in DPPH radical scavenging activity of mulberry juice, mulberry vinegar, and apple vinegar (B).

MJ, mulberry juice; MV, mulberry vinegar; AV, commercial apple vinegar.

Values are mean \pm SD. ${ }^{\text {a-d }}$ Means with the different letters on the bars are significantly different by Duncan's multiple range test $(\mathrm{p}<0.05)$.

등, 2014; Kwon 등 2005). 오디 주스가 식초로 발효가 됨에 따라 총 페놀 함량과 플라보노이드 함량은 다소 감소하였으 나 DPPH 라디칼 소거능이 유사하게 나타난 이유는 식초의 유기산이 carboxyl에 음전하( $\left.\mathrm{COO}^{-}\right)$를 띄고 있어 전자를 공 여할 수 있는 성질이 있으므로 이를 통해 항산화 활성에 기여 했을 것으로 생각된다.

\section{오디 주스와 오디 식초의 $\mathrm{OH}$ 라디칼 소거 활성}

자유 라디칼은 세포가 호기성 환경에 노출되어있는 한 미토콘드리아 내 전자전달계에서 끊임없이 생산되는데, 그 중 $\mathrm{OH}$ 라디칼은 생체 내에서 발생하는 $\mathrm{ROS}$ 중에서 산화적 손상에 가장 독성이 강하고 반응성이 매우 커 인접한 생체 분자에 지질 산화, DNA 손상 및 돌연변이를 유발하여 다양 한 질환의 발병에 관여한다(Althaus 등, 1994; Machlin 등, 1987). 정상적인 경우, $\mathrm{OH}$ 라디칼은 fenton 반응에 의해 $\mathrm{O}_{2}{ }^{-}$ 와 $\mathrm{H}_{2} \mathrm{O}_{2}$ 로부터 생성되며, 활성산소종인 $\mathrm{ONOO}^{-}$의 분해에 의 해 생성되기도 한다(Freeman과 Carpo, 1982). 오디 주스, 오 디 식초 및 시판 사과 식초의 $\mathrm{OH}$ 라디칼 소거능을 살펴본 결과(Fig. 4), 오디 주스와 오디 식초는 농도 유의적으로 소거 활성이 증가하였고, 시판 사과 식초보다 높은 $\mathrm{OH}$ 라디칼 소 거 활성을 나타냈으며, 발효에 따른 라디칼 소거 효과에는 큰
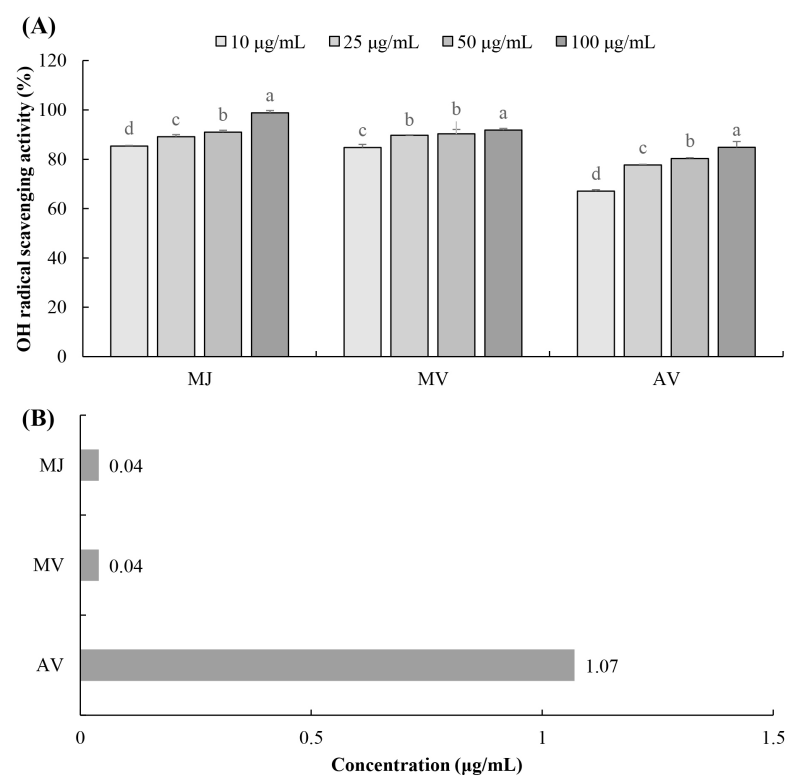

Fig. 4. $\mathrm{OH}$ radical scavenging activity of mulberry juice, mulberry vinegar, and apple vinegar (A). $\mathrm{IC}_{50}$ values in $\mathrm{OH}$ radical scavenging activity of mulberry juice, mulberry vinegar, and apple vinegar (B).

MJ, mulberry juice; MV, mulberry vinegar; AV, commercial apple vinegar.

Values are mean \pm SD. ${ }^{\text {a-d }}$ Means with the different letters on the bars are significantly different by Duncan's multiple range test $(p<0.05)$.

차이를 나타내지 않았다. 특히 오디 주스와 오디 식초는 $\mathrm{IC}_{50}$ 값이 $0.04 \mu \mathrm{g} / \mathrm{mL}$ 를 나타내었고, $10 \mu \mathrm{g} / \mathrm{mL}$ 의 낮은 농도에서 도 $80 \%$ 이상의 소거능을 나타내어 $\mathrm{OH}$ 라디칼에 대한 강력 한 항산화 효과를 가지는 것을 확인하였다. 따라서 오디 식초 의 이러한 라디칼 소거 효과는 체내에서 발생하는 산화적 스 트레스를 줄여주는데 도움을 줄 것으로 생각된다.

\section{오디 주스와 오디 식초의 NO 라디칼 소거 활성}

$\mathrm{NO}$ 는 생체 내에서 항상 일정한 농도로 생성되어 혈액응 고 및 혈압조절 기능 등 생리적 기능 유지 역할을 한다 (Nakagawa와 Yokozawa, 2002). 또한, $\mathrm{NO}$ 는 감염질환, 스트 레스 및 종양형성 초기에 숙주방어를 위해 다양한 면역세포 들이 활성화되면 과다하게 생성되어 감염을 일으키는 병원균 을 공격하거나, 암 초기단계에 종양세포를 파괴하여 생체를 보호한다(Lipton, 1999). 그러나 과다하게 생성된 $\mathrm{NO}$ 는 $\mathrm{O}_{2}{ }^{-}$ 와 결합하여 반응성이 크고 독성이 강한 산화제인 $\mathrm{ONOO}^{-}$를 생성하는데, 이는 단백질, DNA 등과 반응하여 세포 및 조직 손상을 야기하고, 알츠하이머병이나 파킨슨병과 같은 퇴행성 질환에도 중요한 요인으로 작용하는 것으로 알려져 있다 (Althaus 등, 1994; Lee 등, 2009; Lee와 Kim, 2009). NO는 생리적 $\mathrm{pH}$ 상태(pH 7.4)의 $\mathrm{SNP}$ 용액에서 자연스럽게 생성 
되며, Griess reagent로 산소와 반응한 아질산염 생성량을 확 인할 수 있다(Green 등, 1982). 본 실험에서 SNP를 이용하여 $\mathrm{NO}$ 소거 활성을 측정한 결과(Fig. 5), 오디 주스와 오디 식초 모두 농도 의존적으로 증가하는 경향을 보였으며, 모든 농도 에서 시판 사과 식초보다 높은 NO 라디칼 소거 활성을 나타 내었다. 특히 오디 주스와 오디 식초의 경우 $100 \mu \mathrm{g} / \mathrm{mL}$ 농도 에서 각각 $51.25 \%$ 와 $45.24 \%$ 의 가장 높은 $\mathrm{NO}$ 소거 효과를 나타냈으며, 오디 주스가 오디 식초에 비해 다소 낮은 $\mathrm{IC}_{50}$ 값을 나타낸 것은 오디 주스의 총 페놀 및 플라보노이드 함량 이 상대적으로 높기 때문인 것으로 사료된다(van Acker 등, 1995).

\section{오디 주스와 오디 식초의 $\mathrm{O}_{2}^{-}$라디칼 소거 활성}

$\mathrm{O}_{2}^{-}$라디칼은 활성산소종 중에서 가장 먼저 생성되고 반응 성이 약하지만, 일부 분자를 직접 공격할 수 있다. 예를 들어, glutathione peroxidase를 불활성화 시킬 수 있으며, $\mathrm{DNA}$ 를 직접적으로 변형시키지는 못하지만 transition metals이 존재할 때 $\mathrm{OH}$ 라디칼 형성을 촉진한다(Kaur와 Kapoor, 2002). Fig. 6 에서 보는 바와 같이 오디 주스와 오디 식초 모두 농도 의존 적으로 $\mathrm{O}_{2}^{-}$라디칼을 소거하는 것으로 나타났으며, 시판 사과 식초보다 더 높은 소거능을 나타내었다. 특히 오디 식초의
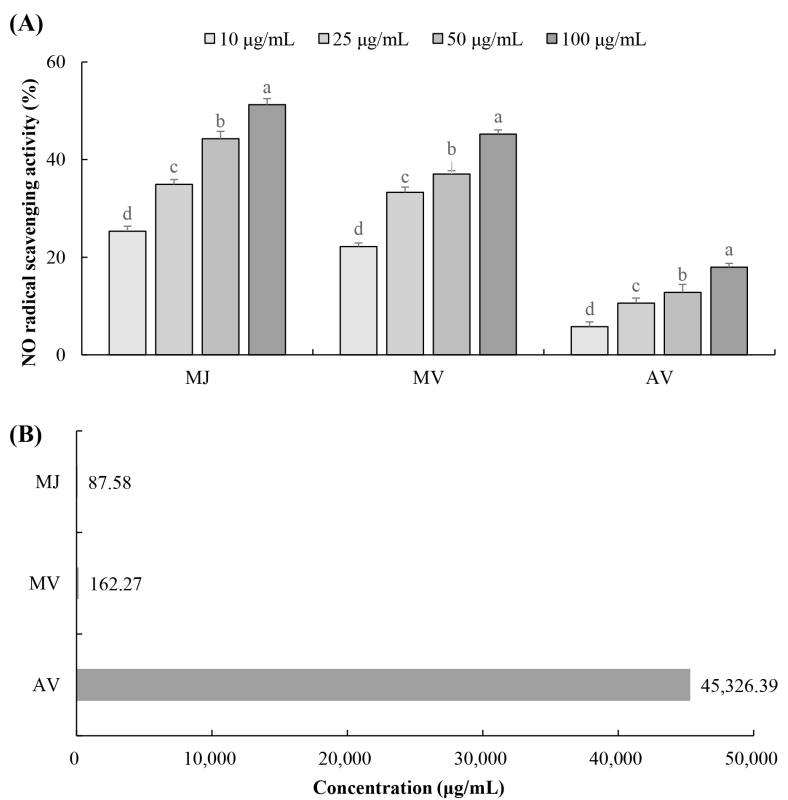

Fig. 5. NO radical scavenging activity of mulberry juice, mulberry vinegar, and apple vinegar (A). $\mathrm{IC}_{50}$ values in $\mathrm{NO}$ radical scavenging activity of mulberry juice, mulberry vinegar, and apple vinegar (B).

MJ, mulberry juice; MV, mulberry vinegar; $\mathrm{AV}$, commercial apple vinegar.

Values are mean \pm SD. ${ }^{\text {a-d }}$ Means with the different letters on the bars are significantly different by Duncan's multiple range test $(\mathrm{p}<0.05)$.
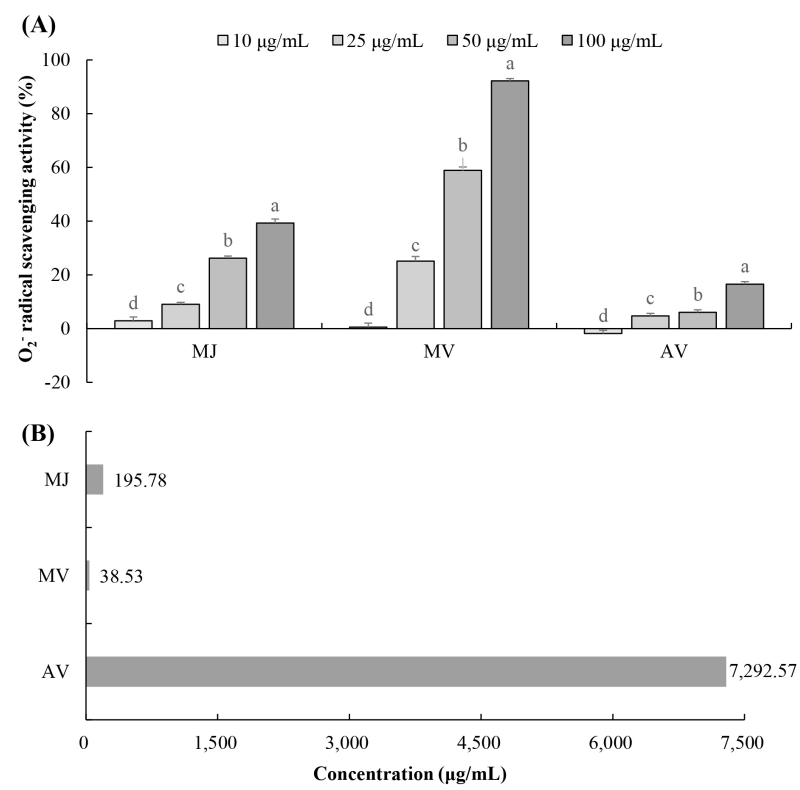

Fig. 6. $\mathrm{O}_{2}^{-}$radical scavenging activity of mulberry juice, mulberry vinegar, and apple vinegar (A). $\mathrm{IC}_{50}$ values in $\mathrm{O}_{2}^{-}$radical scavenging activity of mulberry juice, mulberry vinegar, and apple vinegar (B).

MJ, mulberry juice; MV, mulberry vinegar; $\mathrm{AV}$, commercial apple vinegar.

Values are mean \pm SD. ${ }^{\text {a-d }}$ Means with the different letters on the bars are significantly different by Duncan's multiple range test $(\mathrm{p}<0.05)$.

$\mathrm{IC}_{50}$ 은 $38.53 \mu \mathrm{g} / \mathrm{mL}$ 로 오디 주스 $\left(\mathrm{IC}_{50}, 195.78 \mu \mathrm{g} / \mathrm{mL}\right)$ 보다 높 은 $\mathrm{O}_{2}^{-}$라디칼 소거 효과를 나타내었다. 이전 연구에 따르면 발효 과정 중에 생긴 유기산 등 추가적인 유효성분이 라디칼 소거 활성을 향상시킨다고 보고된 바 있으며, 오디 주스에 비 해 오디 식초에 많이 함유되어 있는 아미노산인 lysine이 항산 화 효능이 있다고 알려져 있다(Al-Malki, 2015; Li 등, 2013). 그러나 lysine이 식초의 항산화 작용에 어떠한 기전을 통해 영 향을 나타내었는지에 대한 추후 연구가 필요한 것으로 생각되 며, 각 라디칼에 결합하는 유효 물질의 종류에 따라 라디칼 소거능이 다르게 나타났을 가능성이 있을 것으로 사료된다.

\section{요 약}

본 연구에서는 오디 주스와 오디 식초의 이화학적 특성 및 in vitro 라디칼 소거 효과를 알아보았다. 오디를 착즙 하여 주스를 제조한 뒤 8 일간의 알코올 발효와 20 일간의 초 산 발효 과정을 거쳐 산도 $6.05 \%$ 와 $\mathrm{pH} 3.06$ 의 오디 식초를 생산할 수 있었다. 오디 식초의 주요 유리당은 sucrose, glucose 및 lactose로 나타났으며, 유기산은 acetic acid 함량이 $2,725.59 \mathrm{mg} \%$ 로 가장 높았고, 이어서 citric acid와 succinic acid가 높게 나타났다. 오디 주스를 발효시킨 오디 식초에서 
유리아미노산의 총 함량은 다소 감소하였으나, lysine과 ornithine의 함량은 증가하는 것을 확인할 수 있었으며, 총폴 리페놀 및 플라보노이드 함량은 각각 $778.06 \mu \mathrm{g} \mathrm{GAE} / \mathrm{mL}$ 와 $294.67 \mu \mathrm{g} \mathrm{QE} / \mathrm{mL}$ 를 함유하고 있는 것을 알 수 있었다. 항산 화 활성을 알아보기 위해 $\mathrm{DPPH}, \mathrm{OH}, \mathrm{O}_{2}{ }^{-}$와 $\mathrm{NO}$ 라디칼 소 거 효과를 측정한 결과, 오디 주스와 오디 식초 모두 10-100 $\mu \mathrm{g} / \mathrm{mL}$ 의 농도에서 농도 의존적으로 라디칼 소거능이 증가하 였으며, 오디 식초가 오디 주스에 비해 $\mathrm{NO}$ 라디칼 소거능은 다소 낮았으나, 시판 사과 식초에 비해서는 높은 라디칼 소거 활성을 나타내는 것을 확인할 수 있었다. 특히 $\mathrm{DPPH}$ 와 $\mathrm{OH}$ 라디칼의 경우, 오디 주스와 오디 식초는 유사한 $\mathrm{IC}_{50}$ 값을 나타내었으며, $\mathrm{O}_{2}^{-}$라디칼 소거능에서는 오디 식초가 오디 주 스에 비해 더 강한 라디칼 소거효과를 나타내었다. 따라서 본 연구결과를 통해 오디를 활용하여 항산화 효능을 가진 기능 성 전통 발효식초로 활용할 수 있는 가능성을 제시할 수 있으 며, 관능적 특성 및 항산화 효능을 나타내는 성분 변화에 대 한 연구가 추가적으로 필요할 것으로 사료된다.

\section{감사의 글}

이 성과는 정부(과학기술정보통신부)의 재원으로 한국연구 재단의 지원을 받아 수행된 연구임(No. 2019R1G1A1100315).

\section{Conflict of interests}

The authors declare no potential conflict of interest.

\section{ORCID}

Se-In Bang

Ah Young Lee

Weon Taek Seo
https://orcid.org/0000-0002-5833-747X https://orcid.org/0000-0002-3489-7798

https://orcid.org/0000-0002-6187-4487

\section{References}

Al-Malki AL. Suppression of acute pancreatitis by L-lysine in mice. BMC Complement Altern Med, 15, 193 (2015) Althaus JS, Oien TT, Fici GJ, Scherch HM, Sethy VH, Von Voigtlander PF. Structure activity relationships of peroxynitrite scavengers an approach to nitric oxide neurotoxicity. Res Commun Chem Pathol Pharmacol, 83, 243-254 (1994)

Andlauer W, Stumpf C, Furst P. Influence of the acetification process on phenolic compounds. J Agric Food Chem, 48, 3533-3536 (2000)
Baek CH, Jeong DH, Baek SY, Choi JH, Park HY, Choi HS, Jeong ST, Kim JH, Jeong YJ, Kwon JH, Yeo SH. Quality characteristics of farm-made brown rice vinegar via traditional static fermentation. Korean J Food Preserv, 20, 564-572 (2013)

Baek SY, Kim JS, Mun JY, Lee CH, Park YK, Yeo SH. Quality characteristics of detoxified Rhus verniciflua vinegar fermented using different acetic acid bacteria. Korean J Food Preserv, 23, 347-354 (2016)

Budak NH, Aykin E, Seydim AC, Greene AK, Guzel-Seydim ZB. Functional properties of vinegar. J Food Sci, 79, R757-R764 (2014)

Byun EB, Kim MJ, Kim SJ, Oh NS, Park SH, Kim WS, Song HY, Han JM, Kim KW, Byun EH. Antioxidant activity and neuroprotective effects of ethanol extracts from the core of Diospyros kaki. Korean J Food Sci Technol, 52, 60-66 (2020)

Cho KM, Ahn BY, Seo WT. Lactic acid fermentation of Gamju manufactured using medicinal herb decoction. Korean J Food Sci Technol, 40, 649-655 (2008)

Choi JY, Jo MK, Goo YM, Kim HK, Shin JW, Kim DY, Kim HJ, Lee EH, Kim NH, Cho YJ. Antioxidant activities of phenolic compounds from medicinal plants (Hibiscus esculentus, Cirsium japonicum, Zizania latifolia and Kalopanax pictus). Current Research on Agriculture and Life Science, 33, 57-63 (2015)

Choi MH, Kim KH, Yook HS. Analysis of active components of premature mandarin. J Korean Soc Food Sci Nutr, 48, 557-566 (2019)

Chu ST, Koo JM, Kim SM. Mulberry vinegar beverage. Korea Patent No. 1011433790000 (2012)

Chung SK, Osawa T, Kawakishi S. Hydroxyl radicalscavenging effects of spices and scavengers from brown mustard (Brassica nigra). Biosci Biotechnol Biochem, 61, 118-123 (1997)

Darley-Usmar V, Wiseman H, Halliwell B. Nitric oxide and oxygen radicals: A question of balance. FEBS Lett, 369, 131-135 (1995)

Freeman BA, Crapo JD. Biology of disease: Free radicals and tissue injury. Lab Invest, 47, 412-426 (1982)

Furukawa S, Fujita T, Shimabukuro M, Iwaki M, Yamada Y, Nakajima Y, Nakayama O, Makishima M, Matsuda M, Shimomura I. Increased oxidative stress in obesity and its impact on metabolic syndrome. J Clin Invest, 
114, 1752-1761 (2004)

Green LC, Wagner DA, Glogowski J, Skipper PL, Wishnok JS, Tannenbaum SR. Analysis of nitrate, nitrite, and $\left[{ }^{15} \mathrm{~N}\right]$ nitrate in biological fluids. Anal Biochem, 126, 131-138 (1982)

Hatano T, Edamatsu R, Hiramatsu M, Mori A, Fujita Y, Yasuhara T, Yoshida T, Okuda T. Effects of the interaction of tannins with co-existing substances. VI. Effects of tannins and related polyphenols on superoxide anion radical, and on 1,1-diphenyl-2-picrylhydrazyl radical. Chem Pharm Bull, 37, 2016-2021 (1989)

Heim KE, Tagliaferro AR, Bobilya DJ. Flavonoid antioxidants: Chemistry, metabolism, and structure-activity relationships. J Nutr Biochem, 13, 572-584 (2002)

Hong SM, Kang MJ, Lee JH, Jeong JH, Kwon SH, Seo KI. Production of vinegar using Rubus coreanus and its antioxidant activities. Korean J Food Preserv, 19, 594603 (2012b)

Hong SM, Moon HS, Lee JH, Lee HI, Jeong JH, Lee MK, Seo KI. Development of functional vinegar by using cucumbers. J Korean Soc Food Sci Nutr, 41, 927-935 (2012a)

Hwang JY, Cho HY, Pyo YH. Effect of unpolished rice vinegar containing Monascus-fermented soybean on inhibitory activities of tyrosinase and elastase. J Korean Soc Food Sci Nutr, 45, 149-154 (2016)

Jeong EJ, Park HJ, Cha YJ. Fermented production of onion vinegar and its biological activities. Korean J Food Nutr, 29, 962-970 (2016)

Jo D, Lee HJ, Jeong YJ, Yeo SH, Kwon JH. Quality properties of pear vinegars with high-acidity under different fermentation conditions. Korean J Food Sci Technol, 46, 418-424 (2014)

Jun HI, Kim YA, Kim YS. Antioxidant activities of Rubus coreanus Miquel and Morus alba L. fruits. J Korean Soc Food Sci Nutr, 43, 381-388 (2014)

Kaur C, Kapoor HC. Anti-oxidant activity and total phenolic content of some Asian vegetables. Int J Food Sci Techol, 37, 153-161 (2002)

KFDA. Korea Food Standard Code. Ministry of Food and Drug Safety, Osong, Korea (2020)

Kim DH, Choi JS, Lee MH, Jang HH, Kim HS, Kim DY, Yeo SH, Park HD. Effect of pectinase treatment on extraction yield and physicochemical properties of aronia juice. Korean J Food Preserv, 24, 68-73 (2017) Kim DH. Studies on the production of vinegar from fig. J Korean Soc Food Sci Nutr, 28, 53-60 (1999)

Kim EO, Lee YJ, Lee HH, Seo IH, Yu MH, Kang DH, Choi SW. Comparison of nutritional and functional constituents, and physicochemical characteristics of mulberrys from seven different Morus alba L. Cultivars. J Korean Soc Food Sci Nutr, 39, 1467-1475 (2010)

Kim HB, Bang HS, Lee HW, Seuk YS, Sung GB. Chemical characteristics of mulberry syncarp. Korean J Seric Sci, 41, 123-128 (1999)

Kim HB, Ryu KS. Sensory characteristics of mulberry fruit jam and wine. Korean J Seric Sci, 42, 73-77 (2000)

Kim SK. Beneficial medicine, mulberry fruit. In: Bonchohak, Younglimsa, Seoul, Korea, p 598-605 (1991)

Kwon YJ, Rhee SJ, Chu JW, Choi SW. Comparison of radical scavenging activity of extracts of mulberry juice and cake prepared from mulberry (Morus spp.) fruit. J Food Sci Nutr, 10, 111-117 (2005)

Lee DS, Ryu IH, Lee KS, Shin YS, Chun SH. Optimization in the preparation of aloe vinegar by Acetobacter sp. and inhibitory effect against lipase activity. J Korean Soc Agric Chem Biotechnol, 42, 105-110 (1999b)

Lee EK, Kwon WY, Lee JW, Yoon JA, Chung KH, Song BC, An JH. Quality characteristics and antioxidant activity of vinegar supplemented added with Akebia quinata fruit during fermentation. J Korean Soc Food Sci Nutr, 43, 1217-1227 (2014)

Lee KI, Kim SM. Antioxidative and antimicrobial activities of Eriobotrya japonica Lindl. leaf extracts. J Korean Soc Food Sci Nutr, 38, 267-273 (2009)

Lee MK, Choi SR, Lee J, Choi YH, Lee JH, Park KU, Kwon $\mathrm{SH}$, Seo KI. Quality characteristics and anti-diabetic effect of yacon vinegar. J Korean Soc Food Sci Nutr, 41, 79-86 (2012)

Lee SG, Kim HJ, Lee SP, Lee IS. Antioxidant and anticancer activities of defatted soybean grits fermented by Bacillus subtilis NUC1. J Korean Soc Food Sci Nutr, 38, 657-662 (2009)

Lee SJ, Kim SH, Kim SY, Yeo SH. Quality characteristics of Kujippong (Cudrania tricuspidata) vinegar fermented by various acetic acid bacteria. Korean J Food Preserv, 26, 766-776 (2019)

Lee YC, Jang OY, Kim HW, Choi CU, Yoon SK. Physico- 
chemical characteristics of traditional vinegars in Andong province. Korean J Dietary Culture, 14, 17-20 (1999a)

Lee YJ, Ha RJ, Seo WT. Physicochemical properties of persimmon vinegars produced from independent two-step fermentation. J Agric Life Sci, 52, 107-122 (2018)

Li XY, Tang L, Hu K, Liu Y, Jiang WD, Jiang J, Wu P, Chen GF, Li SH, Kuang SY, Feng L, Zhou XQ. Effect of dietary lysine on growth, intestinal enzymes activities and antioxidant status of sub-adult grass carp (Ctenopharyngodon idella). Fish Physiol Biochem, 40, 659-671 (2014)

Lipton SA. Neuronal protection and destruction by NO. Cell Death Differ, 6, 943-951 (1999)

Machlin LJ, Bendich A. Free radical tissue damage: Protective role of antioxidant nutrients. FASEB J, 1, 441-445 (1987)

Marcocci L, Maguire JJ, Droylefaix MT, Packer L. The nitric oxide-scavenging properties of Ginkgo biloba extract EGb 761. Biochem Biophys Res Commun, 201, 748-755 (1994)

Moinard C, Caldefie F, Walrand S, Felgines C, Vasson MP, Cynober L. Involvement of glutamine, arginine, and polyamines in the action of ornithine $\alpha$-ketoglutarate on macrophage functions in stressed rats. J Leukocyte Biol, 67, 834-840 (2000)

Moon YJ, Soh JR, Yu JJ, Sohn HS, Cha YS, Oh SH. Intracellular lipid accumulation inhibitory effect of Weissella koreensis OK1-6 isolated from kimchi on differentiating adipocyte. J Appl Microbiol, 113, 652658 (2012)

Nakagawa T, Yokozawa T. Direct scavenging of nitric oxide and superoxide by green tea. Food Chem Toxicol, 40, 1745-1750 (2002)

Nakanc S. Food useful for preventing alcohol in toxication containing persimmon-vinegar and optimum fruits, with blood alcohol concentration reducing action. Japan Patent, 63, 562-566 (1988)

Nishikimi M, Rao NA, Yagi K. The occurrence of superoxide anion in the reaction of reduced phenazine methosulfate and molecular oxygen. Biochem Biophys Res Commun, 46, 849-854 (1972)

Park EH, Choi CY, Kwon HJ, Kim MD. Literature review on type and manufacturing methods of Korean traditional vinegar. Food Science and Industry, 49, 94-99 (2016)

Patel RP, McAndrew J, Sellak, H, White CR, Jo H,
Freeman BA, Darley-Usmar VM. Biological aspects of reactive nitrogen species. Biochim Biophys ActaBioenergetics, 1411, 385-400 (1999)

Shin JH, Kang MJ, Byun HU, Bea WY, Shin JY, Seo WT, Choi JS, Shin JH. Quality characteristics of fermented vinegar prepared with Seomaeyaksuk (Artemisia argyi H.) extract. Korean J Food Preserv, 24, 647-657 (2017) Shin JH. A study on the production of domestic wheat (Keumkangmil) vinegar with mugwort. MS Thesis, Gyeongnam National University of Science and Technology, Korea, p 8 (2013)

Sim HJ, Seo WT, Choi MH, Kim KH, Shin JH, Kang MJ. Quality characteristics of vinegar added with different levels of black garlic. Korean J Food Cook Sci, 32, 16-26 (2016)

Son WR, Choi SW. Biological activity and analysis of $\alpha$ glucosidase inhibitor from mulberry (Morus alba L.) wine. Korean J Food Preserv, 20, $877-885$ (2013)

Song W, Wang HJ, Bucheli P, Zhang PF, Wei DZ, Lu YH. Phytochemical profiles of different mulberry (Morus sp.) species from China. J Agric Food Chem, 57, 9133-9140 (2009)

Su MS, Chien PJ. Antioxidant activity, anthocyanins, and phenolics of rabbiteye blueberry (Vaccinium ashei) fluid products as affected by fermentation. Food Chem, 104, 182-187 (2007)

Tsao R. Chemistry and biochemistry of dietary polyphenols. Nutrients, 2, 1231-1246 (2010)

Turker G, Kizilkaya B, Arifoglu N. Determination of organic acid composition and free radical scavenging capacity of Kefir. Asian J Chem, 26, 2443-2446 (2014)

van Acker SABE, Tromp MNJL, Haenen GRMM, van der Vijgh WJF, Bast A. Flavonoids as scavengers of nitric oxide radical. Biochem Biophys Res Commun, 214, 755-759 (1995)

Wang KJ, Zhang YJ, Yang CR. Antioxidant phenolic compounds from rhizomes of Polygonum paleaceum. J Ethnopharmacol, 96, 483-487 (2005)

Woo SM, Yeo SH, Kwon JH, Kim SH, Jeong YJ. Quality characteristics of high-acidity vinegar prepared with grape juice. Korean J Food Preserv, 22, 100-107 (2015)

Yulkimichi K, Yasuhiro U, Fujiharu Y. The general composition, inorganic cations, free amino acids and organic acids of special vinegars. Nippon Shokuhin Kogyo Gakkaishi, 34, 592-597 (1987) 